Gut, 1972, 13, 331-340

\title{
Partial gastrectomy for haemorrhage
}

\author{
J. R. COCKS, A. M. DESMOND, B. F. SWYNNERTON, AND N. C. TANNER
}

From St. James's Hospital, Balham, London

SUMMARY An analysis was made of the results of 566 partial gastrectomies for haemorrhage from gastroduodenal ulceration between 1953 and 1962 with regard to mortality, morbidity, and long-term follow up.

With rigid criteria for selection of patients for surgery, the overall mortality rate for ulcerative gastroduodenal haemorrhage was $8.6 \%$. The actual operative mortality rate more than doubles if an emergency operation is performed later than four days after the patient's admission with haemorrhage.

Postoperative and later bleeding complications occurred in $5 \%$ of patients.

Regardless of the length of ulcerative history, over $92 \%$ of patients have clinically satisfactory long-term results. Six per cent required further operation, after which, they too had clinically satisfactory results.

Gastroduodenal haemorrhage due to peptic ulceration still carries with it a significant mortality and morbidity, despite our increased knowledge of the pathology of the circulatory changes which take place, and, as a consequence, recent improvements in resuscitation techniques.

There have been many papers written on the short-term results of a particular regime of management in this condition, but very few indeed on the long-term follow up of these patients. While it is realized that the prime motive in the treatment of this catastrophe is to save life in the early phase, before discussing the complete merits of any particular regime it seems proper to analyse the long-term effects of that regime as part of the overall management.

In the Gastric Unit at St James' Hospital, Balham, where gastrointestinal haemorrhage has been a particular interest since 1940, 3179 patients were admitted with bleeding due to peptic ulceration or gastritis up to the end of 1967. The definitive diagnoses can be seen in Table $I$.

The particular routine for managing these cases which was evolved after clinical trials before 1950 (published by Desmond in 1962) has remained essentially unchanged since.

The first step has always been to obtain adequate resuscitation of the patient, and then proceed to the various diagnostic investigations.

Barium studies, in the early years, were usually performed when the patient had ceased bleeding and thus possibly not for some four to five days after Received for publication 14 February 1972.

\begin{tabular}{lr}
\hline Diagnosis & No. of Cases \\
\hline Duodenal ulcer & 1308 \\
Gastric ulcer & 1337 \\
Gastritis & 271 \\
Hiatus hernia and/or oesophageal ulcer & 112 \\
Recurrent ulcer & 151 \\
Total & 3179 \\
Other known causes of bleeding & 271 \\
Undiagnosed bleeding & 129 \\
Grand total & 3579 \\
\hline
\end{tabular}

Table I Causes of gastroduodenal haemorrhage 1940-1967

admission. This plan has slowly altered over the years and now these studies are usually performed in the first 24 hours, and certainly within the first $\mathbf{4 8}$ hours. Definitive diagnoses have thus been made earlier.

Gastroscopy, as an aid to diagnosis, has been utilized throughout the life of the unit, and nearly all patients have been gastroscoped (recently, with the fiberoptic gastroscope) within the first $\mathbf{4 8}$ hours of a haemorrhage. It has been found that the best time for this investigation is within the first $\mathbf{4 8}$ hours, before small lesions, such as gastritis, acute erosions, or Mallory-Weiss tears, have healed (Tanner, 1964). Early gastroscopy in this series has probably been the main reason why the undiagnosed number is so small, relative to many other similar quoted series.

Since 1950 the selection of patients for surgery has been the result of careful study, and this policy has been strictly adhered to since (Table II). In Table II 'severe haemorrhage' refers to a patient who has 331 


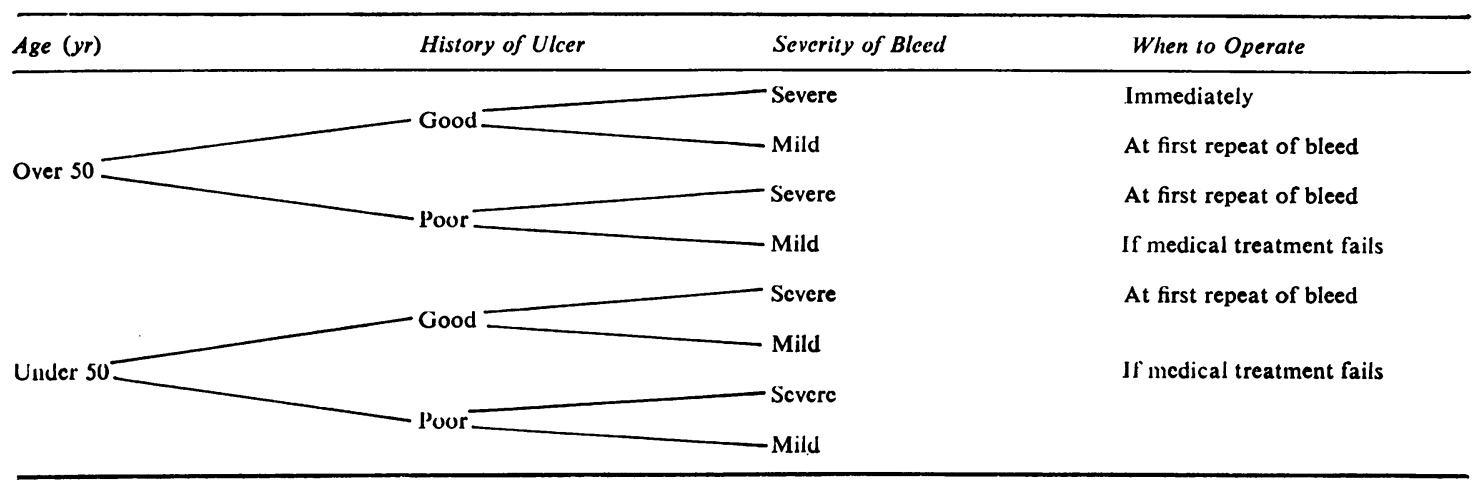

Table II Circumstances indicating when to operate in cases of gastroduodenal bleeding (Desmond, 1962)

become 'shocked' from the haemorrhage, where the systolic blood pressure falls below $100 \mathrm{mg} \mathrm{Hg}$ or if the haemoglobin falls below $\mathrm{g} 7 \%$. Mild haemorrhage has been regarded as anything short of this. Absolute indications for surgery in any case are bleeding associated with perforation or stenosis, persisting severe ulcer pain, and continuous bleeding.

Once surgical treatment has been decided upon, partial gastrectomy has been the procedure of election throughout.

\section{Material and Methods}

A group of 566 consecutive partial gastrectomies for haemorrhage in patients with gastroduodenal ulceration performed between 1953 and 1962 was chosen, and these patients have been followed for periods ranging from five to 15 years. It is a retrospective review in which the method of follow up has been from complete case records, personal interview, and questionnaire. Questionnaires were sent to all patients under the age of 80 at the time of operation who had not been seen personally during the years 1967 and 1968.

These 566 partial gastrectomies were performed from a total of 1427 patients admitted with bleeding during that particular period. Three hundred and sixty-seven were performed as emergencies to control haemorrhage, and 199 for failed medical treatment. The latter patients were assessed as deserving of surgery on previous medical grounds, taking into consideration a history of ulcer, previous bleeding, or perforation. They were treated for this particular episode of bleeding conservatively and subsequently had an elective operation.

During this time there were also 40 other operations performed for bleeding, which ranged from stab drainage of the peritoneal cavity for associated perforation in a moribund gentleman, to vagotomy and underrunning procedures.

\section{Results}

\section{AGE/SEX INCIDENCE}

Of the 566 patients, 248 males and 119 females came to emergency surgery, a ratio of $2: 1$, and 157 males and 42 females had elective partial gastrectomy, a ratio of $4: 1$.

One hundred and fifty $(23 \%)$ of those admitted with duodenal ulcer had emergency surgery compared with $166(30 \%)$ of gastric ulcer patients. The age distribution of those requiring emergency operation compared with the total admitted can be seen in Figures 1 and 2. With duodenal ulcers, the mean age of those admitted was 55 years and those operated on was 61 years. With gastric ulcers the mean age of both those admitted and operated upon was 62 years, the sex incidence being roughly equal, but the mean age of the females was slightly higher than of the males.

Twenty-eight per cent of females and $22 \%$ of males with duodenal ulcer required emergency surgery compared with $25 \%$ of females and $36 \%$ of males with gastric ulcer.

\section{OVERALL MORTALITY}

The overall mortality of all cases admitted during the 10-year period can be seen in Table III. The overall mortality was $8.6 \%$ and it can be seen how the mortality increases markedly with age up to $23 \%$ for patients over 80 years of age.

\begin{tabular}{lcc}
\hline Age $(y r)$ & No. of Patients & Mortality (\%) \\
\hline Under 50 & $424(30 \%)$ & 0.5 \\
Over 50 & $1003(70 \%)$ & 12.0 \\
Over 60 & $714(50 \%)$ & 15.0 \\
Over 70 & $421(30 \%)$ & 19.0 \\
Over 80 & $109(8 \%)$ & 23.0 \\
Total & $1427(100 \%)$ & 8.6 \\
\hline
\end{tabular}

Table III Overall mortality for haemorrhage from gastroduodenal ulceration 1953-1962 


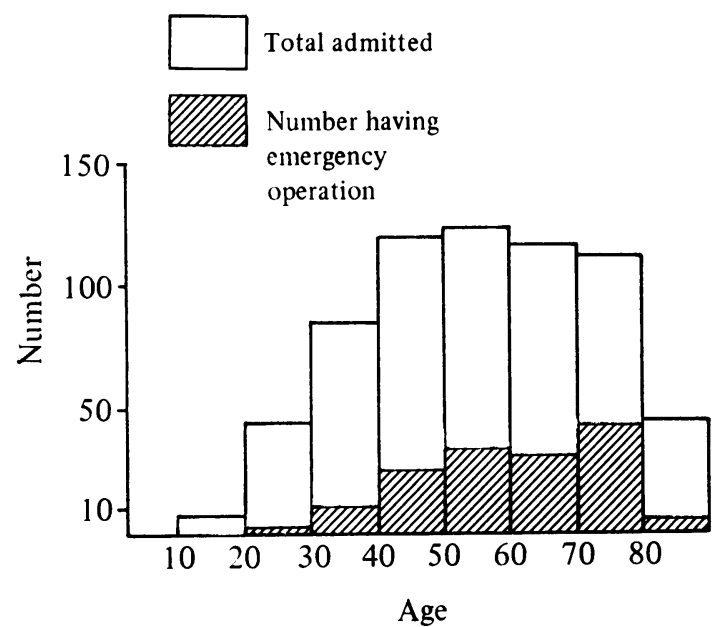

Fig. 1 Age distribution of patients with duodenal ulcer admitted with haemorrhage compared with those requiring operation.

The overall mortality for patients with the individual ulcer is different, being $12 \%$ for gastric ulcer and $7 \%$ for duodenal ulcer, a rough ratio of $2: 1$, which has been constantly found throughout the 30 years' function of the unit, and is in accord with most other series reported.

\section{OPERATIVE MORTALITY}

The operative mortality rates for emergency operation between 1953 and 1962 can be seen in Table IV. If a patient is bleeding severely enough to warrant emergency operation according to the criteria mentioned above, the mortality was roughly double the overall mortality for all age groups.

\begin{tabular}{lcl}
\hline Age $(y r)$ & No. of Patients & Mortality $(\%)$ \\
\hline Under 50 & $72(20 \%)$ & 1.0 \\
Over 50 & $295(80 \%)$ & 22.0 \\
Over 60 & $213(57 \%)$ & 26.0 \\
Over 70 & $112(30 \%)$ & 30.0 \\
Over 80 & $18(5 \%)$ & 44.0 \\
Total & $367(100 \%)$ & 17.0 \\
\hline
\end{tabular}

Table IV Mortality of emergency gastrectomy for haemorrhage from gastroduodenal ulceration 1953-1962

LONG-TERM FOLLOW UP

The overall results for those patients who underwent surgery, analysed according to the Visick classification (1948), are seen in Table V. About 92 to $93 \%$ of both groups have been classified as satisfactory, with very good results in about $91 \%$ of each group. This compares favourably with those long-term

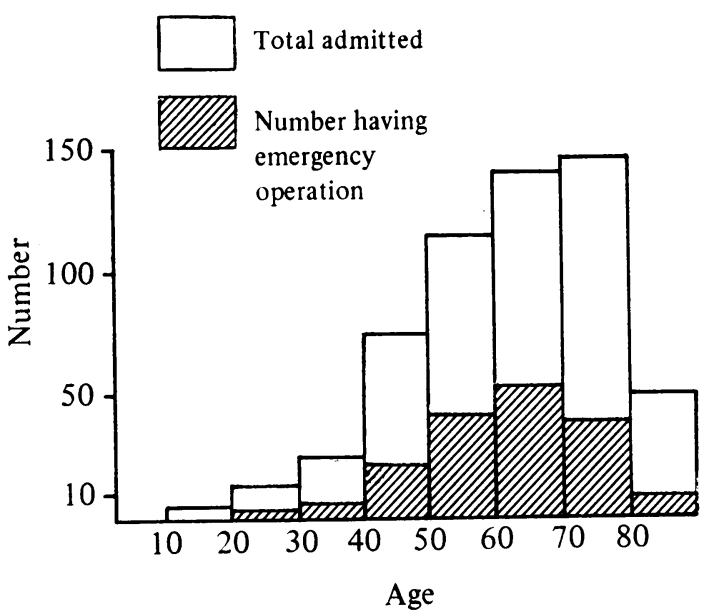

Fig. 2 Age distribution of patients with gastric ulcer admitted with haemorrhage compared with those requiring operation.

\begin{tabular}{|c|c|c|c|}
\hline $\begin{array}{l}\text { Visick } \\
\text { Category }\end{array}$ & $\begin{array}{l}\text { Emegency } \\
\text { Partial } \\
\text { Gastrectomy }\end{array}$ & $\begin{array}{l}\text { Visick } \\
\text { Category }\end{array}$ & $\begin{array}{l}\text { Later Partial } \\
\text { Gastrectomy }\end{array}$ \\
\hline $\begin{array}{l}\text { I } \\
\text { IIIs } \\
\text { IIIu } \\
\text { IV }\end{array}$ & $\begin{array}{r}\left.\begin{array}{r}147 \\
29 \\
6\end{array}\right\} 93 \% \\
2 \\
12 \quad(5 \%)^{1}\end{array}$ & $\begin{array}{l}\text { I } \\
\text { II } \\
\text { IIIs } \\
\text { IIIu } \\
\text { IV }\end{array}$ & $\left.\begin{array}{r}113 \\
11 \\
3\end{array}\right\} 92 \%$ \\
\hline Total & 196 & & 137 \\
\hline $\begin{array}{l}\text { Operative death } \\
\text { Late death } \\
<5 \text { years } \\
\text { Lost to follow up }\end{array}$ & $\begin{array}{ll}64 & (17 \%) \\
32 & \\
75 & \end{array}$ & $\begin{array}{l}\text { Operative death } \\
\text { Late death } \\
<5 \text { years } \\
\text { Lost to follow up }\end{array}$ & $\begin{array}{rr}7 & (3.5 \%) \\
10 & \\
45 & \end{array}$ \\
\hline Grand total & 367 & & 199 \\
\hline Average bed stay & 21 days & Average bed stay & y 14 days \\
\hline
\end{tabular}

Table V Overall results of 566 partial gastrectomies for haemorrhage due to gastroduodenal ulceration followed up for five to 15 years

${ }^{1}$ Figure in brackets represents actual recurrent ulcer rate.

results on all elective cases reported by Tanner in 1959.

Of those classified Visick IIIu, one woman of 77 years had indigestion and some bile regurgitation intermittently, while taking cortisone for rheumatoid arthritis. One woman of 70 years had spasmodic attacks of diarrhoea but is well in between, and one man had intermittent bouts of abdominal pain with repeatedly negative investigations.

The diagnosis and subsequent fate of those classified as Visick grade IV can be seen in Table VI. Apart from one re-operative death for a perforated stomal ulcer, all have been lifted into a satisfactory classification after further operation, so 


\begin{tabular}{|c|c|c|c|c|c|c|c|}
\hline \multicolumn{4}{|c|}{ Initial Findings } & \multicolumn{3}{|l|}{ Subsequent Fate } & \multirow[t]{2}{*}{ Present Visick Class } \\
\hline Sex & Diagnosis & Operation & Date & Diagnosis & Operation & Date & \\
\hline \multicolumn{8}{|c|}{ Emergency Gastrectomy } \\
\hline $\mathbf{M}$ & DU & Polya & 1953 & Stomal & $\begin{array}{l}\text { Oversewn } \\
\text { perforation }\end{array}$ & 1954 & \\
\hline & & & & & $\begin{array}{l}\text { Higher gastrectomy } \\
\text { for bleeding }\end{array}$ & 1954 & I \\
\hline & & & & & Vagotomy & 1955 & \\
\hline $\mathbf{M}$ & DU & Polya & 1953 & Stomal & $\begin{array}{l}\text { Oversewn } \\
\text { perforation }\end{array}$ & 1956 & II \\
\hline & & & & & Vagotomy & 1957 & \\
\hline $\mathbf{M}$ & DU & Polya & 1961 & Stomal & Vagotomy & 1965 & I \\
\hline $\mathbf{M}$ & DU & Polya & 1961 & Stomal & $\begin{array}{l}\text { Oversewn } \\
\text { perforation }\end{array}$ & 1961 & ${ }^{2}$ \\
\hline & & & & & $\begin{array}{l}\text { Oversewn } \\
\text { perforation }\end{array}$ & 1962 & I \\
\hline $\mathbf{M}$ & DU & Polya & 1957 & Stomal & $\begin{array}{l}\text { Higher gastrectomy } \\
\text { Vagotomy, revision } \\
\text { gastrectomy }\end{array}$ & $\begin{array}{l}1962 \\
1960\end{array}$ & II \\
\hline $\mathbf{M}$ & DU & Polya & 1953 & Stomal & Higher gastrectomy & 1965 & II \\
\hline $\mathbf{M}$ & DU & Polya & 1956 & Stomal & $\begin{array}{l}\text { Vagotomy, higher } \\
\text { gastrectomy }\end{array}$ & 1959 & $\begin{array}{l}\text { IIIs } \\
\text { Diarrhoea }\end{array}$ \\
\hline $\mathbf{M}$ & DU & Polya & 1953 & Stomal & $\begin{array}{l}\text { Revision gastrectomy } \\
\text { for perforation }\end{array}$ & 1961 & Operative death \\
\hline $\mathbf{M}$ & GU & $\begin{array}{l}\text { Billroth I } \\
\text { (blind) }\end{array}$ & 1953 & Recurrent GU & Polya & 1965 & 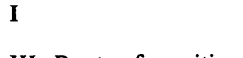 \\
\hline $\mathbf{M}$ & GU & Billroth I & 1958 & Bilious vomiting & Roux conversion & 1965 & IIIs Bouts of vomiting \\
\hline $\mathbf{M}$ & GU & $\begin{array}{l}\text { Billroth I } \\
\text { (blind) }\end{array}$ & 1957 & Recurrent DU & Polya & 1966 & I \\
\hline $\mathbf{F}$ & GU & Billroth I & 1961 & Erosive gastritis & Polya & 1966 & I \\
\hline \multicolumn{8}{|c|}{ Later Gastrectomy } \\
\hline $\mathbf{F}$ & Gastritis & Billroth I & 1953 & Recurrent bleeds & Higher gastrectomy & 1958 & Late death unrelated \\
\hline $\mathbf{F}$ & GU & Billroth I & 1954 & Stomal & Polya & 1965 & II \\
\hline $\mathbf{F}$ & DU & Billroth I & 1955 & Bleed & $\begin{array}{l}\text { Polya, no ulcer } \\
\text { found }\end{array}$ & 1965 & IIIs \\
\hline $\mathbf{M}$ & DU & Polya & 1961 & Stomal & $\begin{array}{l}\text { Oversewn } \\
\text { perforation, vagotomy }\end{array}$ & $y^{1964}$ & I \\
\hline $\mathbf{M}$ & DU & Polya & 1958 & Stomal & $\begin{array}{l}\text { Vagotomy re- } \\
\text { fashioned, higher } \\
\text { gastrectomy }\end{array}$ & 1959 & I \\
\hline $\mathbf{M}$ & DU & Polya & 1960 & Stomal & Vagotomy & 1967 & I \\
\hline $\mathbf{M}$ & DU & Polya & 1958 & Stomal & Vagotomy & 1960 & IIIs Diarrhoea \\
\hline $\mathbf{M}$ & DU & Polya & 1959 & Stomal & Vagotomy & 1963 & I \\
\hline $\mathbf{M}$ & DU & Polya & 1962 & Stomal & $\begin{array}{l}\text { Vagotomy, higher } \\
\text { gastrectomy }\end{array}$ & 1967 & I \\
\hline
\end{tabular}

Table VI Subsequent fate of Visick IV patients after emergency and later gastrectomy

that after these operations $99 \%$ of the total had satisfactory results.

Forty-two patients were found to have died before five years of follow up-none apparently due to further ulcer problems but all of other diseases.

The average stay in hospital was three weeks for those having emergency partial gastrectomy and two weeks for those having a subsequent elective operation.

\section{LONG-TERM MORBIDITY}

The main residual disabilities some patients suffer after operation are seen in Table VII.

Fullness after eating a big meal is a fairly common phenomenon, but most patients find they can eat a smaller meal with no ill effects. Some form of 'dumping' occurs in about one-third of patients, but again usually only after a fairly heavy meal. As has

\begin{tabular}{ll}
\hline Residual Disability & $\begin{array}{l}\text { Percentage of } \\
\text { Total }\end{array}$ \\
\hline Fullness after eating a very big meal & 61 \\
Occasional fullness after average meals & 12 \\
Palpitations after eating & 9 \\
Occasional tiredness after eating & 28 \\
Attacks of diarrhoea & 23 \\
Regained preoperative weight & 59 \\
Reduced weight, but steady & 40 \\
Steadily losing weight & 1 \\
\hline
\end{tabular}

Table VII Residual disabilities after partial gastrectomy for bleeding

been seen (Table $V$ ) it is only very few patients who cannot control these mild symptoms with simple dietary care.

Attacks of diarrhoea occur in $23 \%$ of patients but fortunately in most patients these attacks are very infrequent, perhaps once or twice a year, and rarely 
causing the bowels to open more than two or three times a day. Between attacks they have normal bowel habits.

Almost $60 \%$ of patients after partial gastrectomy for haemorrhage regain their preoperative weight. Only $1 \%$ seemed to be steadily losing weight at the time of review, and these three patients had other disease states as well.

\section{TIMING OF OPERATION}

Figure 3 analyses the connexion between the day of operation and the corresponding mortality. It can be seen that the operative mortality rate rises from $14 \%$ on day 0 to more than double, $33 \%$, if operation is not until the fourth day after admission, and more than trebled, $52 \%$, if operation is not until one week after admission.

All of these patients had emergency operations, but, as can be seen, many were not operated on until several days had elapsed. Either the bleeding was not thought to be as severe on admission as subsequently it proved to be, or bleeding continued unabated, or a further severe episode of bleeding occurred while the patient was in hospital recovering from the first.

\section{SHORT V LONG HISTORY}

One of the main purposes of this review was to verify or refute the statement often made that 'patients who have a partial gastrectomy when there is no significant history do badly'. Table VIII compares the results of those patients who had emergency operation when the history of dyspepsia

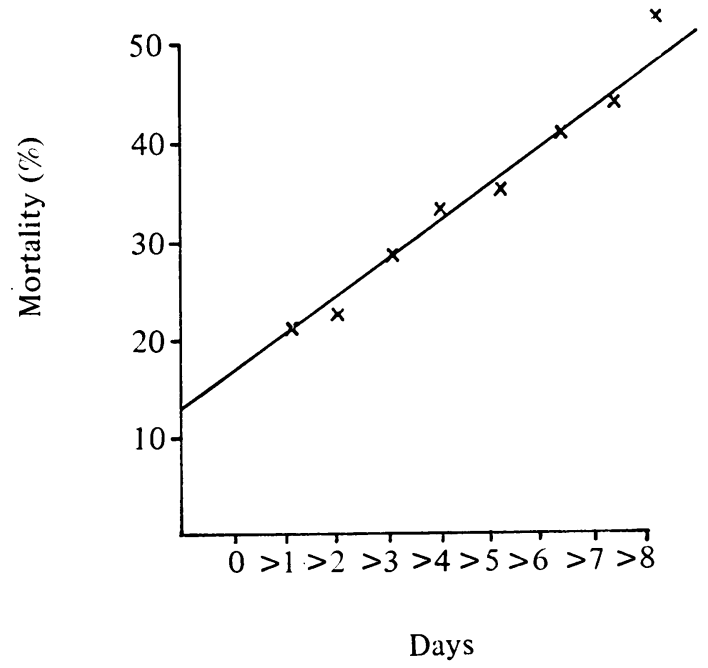

Fig. 3 Mortality rate compared with days from admission to emergency operation

\begin{tabular}{|c|c|c|c|}
\hline Visick Category & $\begin{array}{l}\text { History< } \\
\text { Three Months }\end{array}$ & Visick Category & $\begin{array}{l}\text { History } \\
\text { Three Months }\end{array}$ \\
\hline I & 26) & I & 119) \\
\hline II & $1\} 96 \%$ & II & $24\} 92 \%$ \\
\hline $\mathbf{s}$ & & IIIs & 5) \\
\hline IIIu & & IIIu & 2 \\
\hline \multirow[t]{2}{*}{ IV } & 1 & IV & 11 \\
\hline & 28 & & 161 \\
\hline Operative death & 17 & Operative death & 41 \\
\hline $\begin{array}{l}\text { Late death } \\
<5 \text { years }\end{array}$ & 7 & $\begin{array}{l}\text { Late death } \\
<5 \text { years }\end{array}$ & 23 \\
\hline \multirow[t]{2}{*}{ Lost to follow-up } & 13 & Lost to follow-up & 51 \\
\hline & 65 & & 276 \\
\hline
\end{tabular}

Table VIII Emergency gastrectomies for gastric and duodenal ulceration

was less than three months with those with a history of more than three months. The numbers are naturally small in the 'less than three months' group but there would seem no reason for delaying operation in patients with a history of less than three months on the grounds that they do badly in the long term. The long-term results are similar in both groups. The operative mortality in the 'less than three months' group, however, is $26 \%$ compared with $15 \%$ in the group with a long history.

\section{MORTALITY AND MORBIDITY}

An analysis of the cause of postoperative mortality (Table IX) shows a multiplicity of aetiological factors. Bronchopneumonia was common as many of these patients in London already had severe bronchitis before operation, and anaesthesia, together with the major operation, in this group understandably causes a significant mortality.

About half of the deaths are due to disease unrelated to the gastrointestinal haemorrhage.

\begin{tabular}{lr}
\hline Cause of Postoperative Death & No. \\
\hline Haemorrhage from suture line & 4 \\
Haemorrhage from inadequate underrunning & 1 \\
Unknown upper gastrointestinal haemorrhage & 2 \\
Duodenal stump leakage & 1 \\
Leaking anastomosis & 4 \\
Cardiac arrest on table & 3 \\
Within 24 hours-poor preoperative state & 9 \\
Myocardial infarction & 7 \\
Congestive cardiac failure & 6 \\
Bronchopneumonia & 12 \\
Pulmonary embolus & 4 \\
Enterocolitis & 2 \\
Pancreatitis & 2 \\
Cerebrovascular accident & 3 \\
Uraemia, chronic nephritis & 3 \\
Subphrenic abscess & 3 \\
Associated terminal malignancy & 3 \\
Dissecting aneurysm & 1 \\
Bleeding from adenoma D-J flexure & 1 \\
& 71
\end{tabular}

Table IX Causes of postoperative death 
Wound complications (Table $\mathrm{X}$ ) were the commonest cause of postoperative morbidity, but also noteworthy is the number of patients dying from carcinoma of the lung and the number of patients later developing gallbladder disease or tuberculosis.

Four patients later developed malignancy in the stomach remnant.

\begin{tabular}{lc}
\hline Cause of Postoperative Morbidity & No. of Cases \\
\hline Early & \\
Wound complications- & 10 \\
$\quad$ Stitch abscess & 3 \\
$\quad$ Wound dehiscence & 1 \\
Gastric fistula & 1 \\
Duodenal fistula & 1 \\
Pancreatic fistula & 1 \\
Continued bleeding from retained stomal ulcer & 1 \\
Subphrenic abscess & 1 \\
Lung abscess & 1 \\
Pyaemia & \\
Late & 8 \\
Incisional hernia & \\
Intestinal obstruction- & 4 \\
$\quad$ Adhesions & 2 \\
$\quad$ Bolus & 1 \\
Stammer loop & 1 \\
Homologous serum jaundice & \\
Carcinoma in stomach remnant & 3 \\
Leiomyosarcoma in stomach remnant & 1 \\
Carcinoma of lung & 10 \\
Gall bladder disease & 5 \\
Tuberculosis & 4 \\
\hline
\end{tabular}

Table X Causes of postoperative morbidity

\section{RECURRENT BLEEDING}

In this series there were seven postoperative deaths due to continued or recurrent gastrointestinal bleeding. Three patients were found at necropsy to have bled from the anastomosis, one from erosive gastritis, and one from an inadequate underrun of a duodenal ulcer when the duodenum was closed proximally. The usual practice of the unit is in fact to remove the ulcer, or peel it off the pancreas, and close the stump distal to the ulcer. In two patients no definite bleeding site could be found.

Only one patient had a second operation for bleeding in the postoperative phase, and this came from a stomal ulcer left in the jejunum. This patient survived.

During subsequent years, six patients with stomal ulcers presented with recurrent bleeding. Three patients with erosive gastritis underwent further surgery for recurrent bleeding, and six patients were admitted with recurrent bleeding which was investigated, erosive gastritis diagnosed and conservative therapy proved satisfactory. Four other patients bled again and a definite diagnosis was not made. All of them were treated conservatively and have had no further trouble. One woman died as a result of a recurrence of bleeding but the diagnosis was not established as necropsy was not permitted.

This gives an overall long-term recurrence of bleeding rate of $5 \%$, but only $2.2 \%$ in the postoperative period and first postoperative year, and it is this latter period which is usually quoted when comparing series.

\section{ASSOCIATED PERFORATION}

Twenty patients had a partial gastrectomy for a perforation associated with the initial haemorrhage. Four patients had perforated gastric ulcers and 16 patients had associated perforated duodenal ulcers. Of the gastric ulcer parients, three survived. Of the duodenal ulcer patients, 11 survived. That is, of those patients having a partial gastrectomy for bleeding and associated perforation from an ulcer, only 14 $(70 \%)$ survived the hospital admission. Twelve $(86 \%)$ of those, however, fell into the Visick I category at five years.

During the same 10-year period, five other procedures were performed for associated perforation, with only one survival. This patient had a perforated duodenal ulcer oversewn and a gastrojejunostomy performed, and was classified Visick I at five years.

\section{LATE LABORATORY TESTS}

Late haemoglobin values were estimated on about half those patients who survived longer than five years. Figure 4 shows the distribution, the peak being between 13.0 to $14.5 \%$ g. However, 40 patients $(26 \%)$ had a haemoglobin value of less than $11.6 \% \mathrm{~g}$.

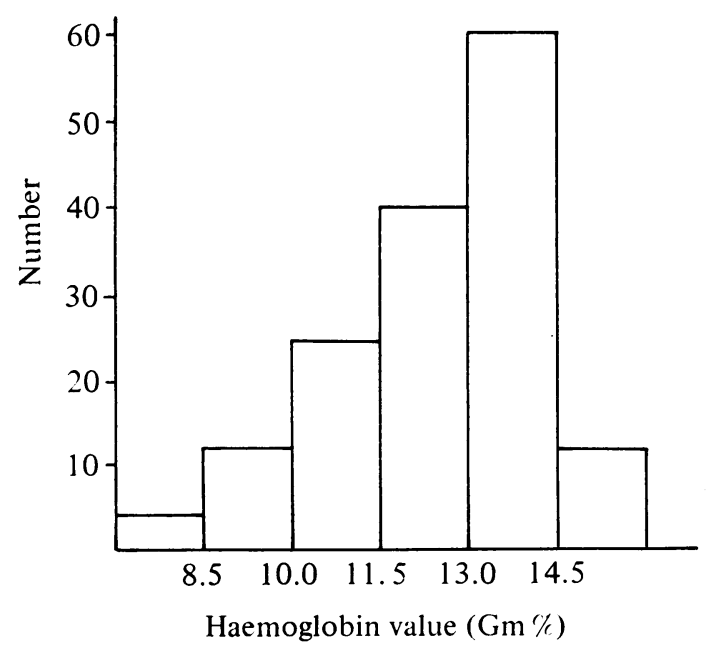

Fig. 4 Haemoglobin estimation at long-term follow up 
There was no correlation between the haemoglobin value and the Visick classification, but when the serum iron values were determined on those patients who had not taken iron, although the numbers were small (Table XI), there did seem to be a better correlation. This has been borne out in clinical practice when it has been found in more recent years that if the serum iron level is low, despite a normal haemoglobin value, giving iron will frequently rid the patient of some postgastrectomy symptoms but more controlled studies must be made.

The serum vitamin $B_{12}$ level had been low in three patients in the series, all of whom had a macrocytic anaemia, and all were taking regular vitamin $B_{12}$ as a result.

\begin{tabular}{lll}
\hline $\begin{array}{l}\text { Serum Iron Value } \\
(\mu g \%)\end{array}$ & No. of Patients & Visick I \\
\hline$<90$ & 90 & $13(65 \%)$ \\
$>90$ & 18 & $15(85 \%)$ \\
\hline
\end{tabular}

Table XI Serum iron estimations
Calcium levels and alkaline phosphatase levels were measured in 39 patients (Table XII). In only one case (case 26) was the calcium level raised above $10.8 \mathrm{mg} \%$ (the upper limit of normal for that laboratory), and this patient has consistently failed to attend for further investigation.

The alkaline phosphatase level was above $13 \mathrm{KA}$ units in five patients (cases 13, 22, 27, 30, and 38four females and one male), but in none of these patients was there clinical evidence of bone disease. If it is true that partial gastrectomy predisposes to later bone disease, perhaps it is these patients who will develop it. None of these biochemically abnormal patients has so far been followed up for longer than eight years, and hence sufficient time may not have yet elapsed for clinical bone disease to manifest itself.

\section{TYPE OF OPERATION}

Tables XIII and XIV show the long-term follow up relating the type of operation to the pathological type of ulcer. The Billroth I type of operation was

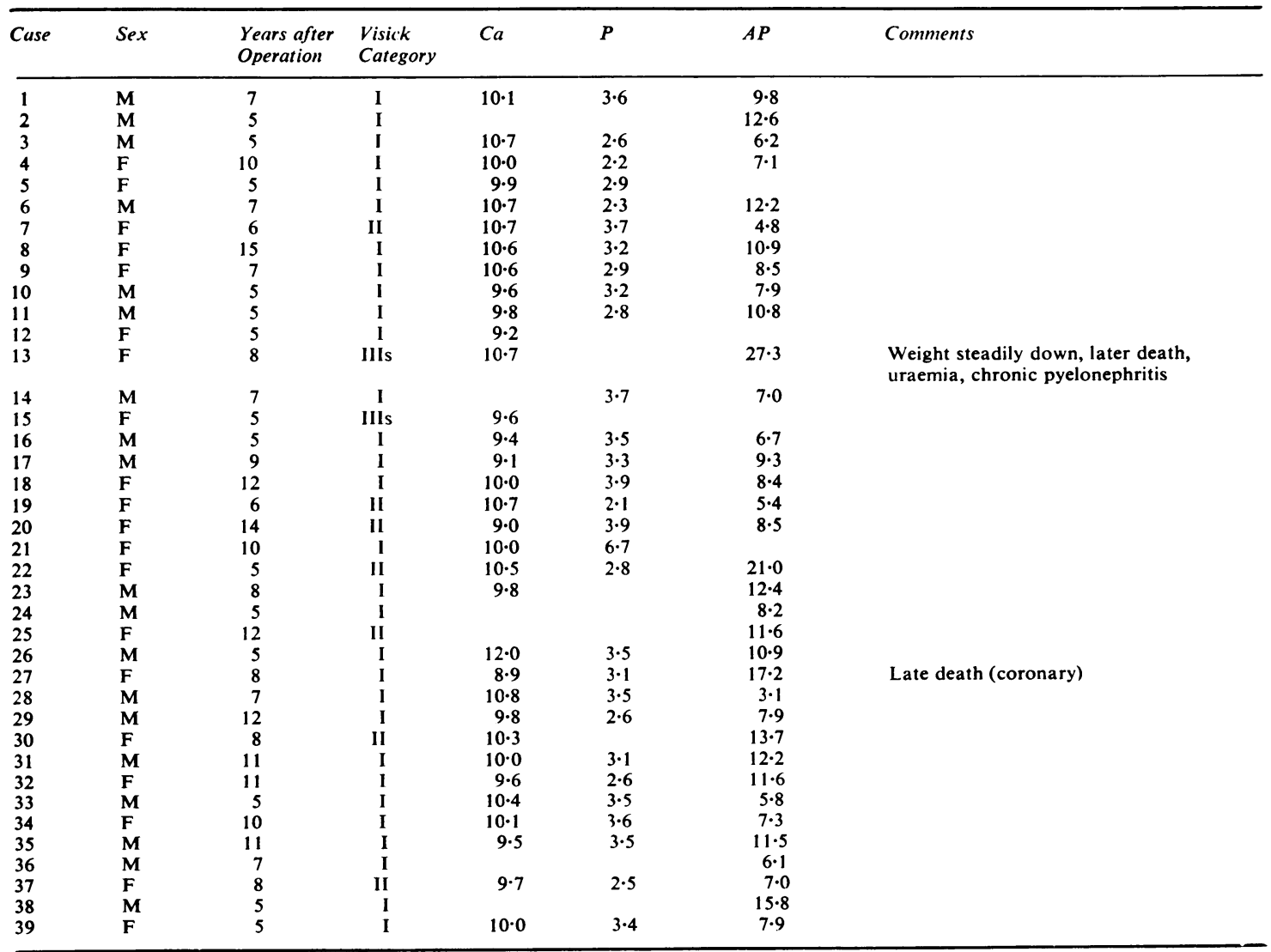




\begin{tabular}{|c|c|c|c|c|c|c|}
\hline & $D U$ & $G U$ & $\begin{array}{l}G U \\
D U\end{array}$ & \&astritis & GJU & Comment \\
\hline \multirow{5}{*}{$\begin{array}{l}\text { Visick I } \\
\text { Visick II } \\
\text { Visick IIIs } \\
\text { Visick IIIu } \\
\text { Visick IV }\end{array}$} & 9 & 88 & 6 & 2 & & \\
\hline & & 17 & & 2 & & \\
\hline & 1 & 1 & & 1 & & Billroth I for \\
\hline & 1 & 1 & & 8 & & gastric ulcer \\
\hline & & & & & & $\begin{array}{l}\text { Satisfactory } \\
95 \%\end{array}$ \\
\hline \multirow{3}{*}{$\begin{array}{l}\text { Operative } \\
\text { death } \\
\text { Late death } \\
\text { Lost to } \\
\text { follow up }\end{array}$} & 1 & 28 & 2 & 3 & & \\
\hline & 1 & 17 & 2 & 1 & 1 & $\begin{array}{l}\text { Recurrent ulcer } \\
\text { rate } 3.6 \%\end{array}$ \\
\hline & 3 & 37 & 4 & 4 & & \\
\hline Total & 16 & 194 & 14 & 14 & 1 & \\
\hline
\end{tabular}

Table XIII Follow up after Billroth I type of gastrectomy for five to 15 years

\begin{tabular}{|c|c|c|c|c|c|c|}
\hline & $D U$ & $G U$ & $\begin{array}{l}G U \\
D U\end{array}$ & \& Gastritis & $G J U$ & Comment \\
\hline \multirow{5}{*}{$\begin{array}{l}\text { Visick I } \\
\text { Visick II } \\
\text { Visick IIIs } \\
\text { Visick IIIu } \\
\text { Visick IV }\end{array}$} & 123 & 18 & 10 & 1 & 3 & \multirow{5}{*}{$\begin{array}{l}\text { Polya for } \\
\text { prepyloric, } \\
\text { pyloric, and } \\
\text { duodenal ulcer }\end{array}$} \\
\hline & 17 & 1 & 2 & 1 & & \\
\hline & 4 & 1 & 1 & & & \\
\hline & & 2 & & & & \\
\hline & 14 & & & & & \\
\hline \multirow{2}{*}{$\begin{array}{l}\text { Operative } \\
\text { death }\end{array}$} & 33 & & & 2 & 2 & \multirow{5}{*}{$\begin{array}{l}\text { Satisfactory } \\
92 \% \\
\text { Recurrent ulcer } \\
\text { rate } 7 \cdot 3 \%\end{array}$} \\
\hline & & & & & & \\
\hline Late death & 10 & 6 & 3 & & & \\
\hline $\begin{array}{l}\text { Lost to } \\
\text { follow up }\end{array}$ & 55 & 4 & 3 & 3 & 5 & \\
\hline Total & 256 & 32 & 19 & 7 & 10 & \\
\hline
\end{tabular}

Table XIV Follow up after Polya gastrectomy for five to 15 years

usually chosen for gastric ulcer, and the Polya operation for duodenal ulcer, but there was some overlap. Thirty-two patients with gastric ulcer had a Polya operation, 13 of these being for prepyloric or pyloric ulceration. Sixteen patients with duodenal ulcers were treated by Billroth I operation with remarkably good results, considering that it is generally believed there is between a 15 and $30 \%$ recurrence rate for this operation.

The Billroth I type of gastrectomy for gastric ulcer with haemorrhage gives $95 \%$ satisfactory results with a recurrent ulcer rate of $3.6 \%$.

The Polya operation for duodenal, prepyloric, and pyloric ulceration, with haemorrhage, gives $92 \%$ satisfactory results, with a recurrent ulcer rate of $7 \cdot 3 \%$.

\section{Discussion}

The surgical management of haemorrhage due to peptic ulceration is still under review. There are many who advocate gastric resection for this disease, but more recently there has been a marked swing in favour of vagotomy and underrunning procedures. Those authors who advocate the latter report that operative mortality rates are lower than with gastric resection, while those authors who favour partial gastrectomy point out that it is the bleeding which needs control and this is more certain with resection procedures.

It was against this background that this series of patients was investigated, not only with mortality and recurrent rates in mind, but also with the results of long-term follow up as they may influence decisions regarding future surgical planning.

The overall mortality rate in this series compares with other gastric resection series of $5.9 \%$ reported by Large in 1960 and $7.7 \%$ reported by MacCaig, Strange, and Norris (1964), particularly bearing in mind that this series contained a much higher percentage of gastric ulcer patients who have a relatively higher mortality rate. This also compares with $9 \%$ reported in the series by Schiller, Truelove, and Williams (1970), when surgeons were predominantly doing vagotomy and underrunning procedures.

Actual operative mortality rates will vary greatly according to the particular criteria of selection for surgery up to $36 \%$ (Foster, Hickok, and Dunphy, 1964; Neilsen and Amdrup, 1968). These figures of themselves mean little unless put into the context of the overall mortality rate for all patients admitted with haemorrhage. For, as Schiller et al (1970) pointed out, despite a policy change from gastrectomy to vagotomy, and a consequent reduction in operative mortality, the overall mortality remained the same, as they were operating on fewer patients and had a correspondingly higher mortality rate in the unoperated patients.

The operative mortality rate of $17 \%$ in this series is to be compared with the mortality of patients treated conservatively and not undergoing surgery of any kind $-5.5 \%$. This is a rather surprising figure but it includes those patients admitted moribund and unfit for surgery and those who die while inpatients with associated disease states. These groups also serve to keep the overall mortality to significant levels. Kelley, Grant, and Elliott (1963) quote a mortality rate of $8 \%$ for those patients they did not operate on.

In more recent years (1963-67), the overall mortality at St James' has been reduced to less than $7 \%$ with a corresponding fall in operative mortality, whilst in the last two years of that period, 1966 and 1967 , the overall mortality dropped to $2.3 \%$ and operative mortality to $5 \%$. Central venous pressure monitoring of resuscitation was introduced during the latter time and no doubt played a significant part in lowering mortality rates. 
With regard to the timing of operation, mortality rises steeply with delay. If a patient bleeds again or continues steadily bleeding, particularly the elderly patient, his general condition becomes worse, and he correspondingly stands late emergency surgery the more poorly. Hence it would seem that a definite decision regarding surgery in a particular patient whose indications for surgery may be in doubt should be made as early as possible. Sir Gordon Gordon-Taylor used to talk about the 'golden 48 hours' in which to make this decision. This probably still applies today. Failure to maintain stability on 3 units of blood in 24 hours after the initial resuscitation seems one of the best criteria in deciding on the necessity for operation in the "continued steady bleeding' group.

Figure 3 showing increased mortality with delay, together with Tables III and IV showing increased mortality with age, tend to suggest, and in fact confirm, what is now well recognized, that early operation in the elderly will give the best overall results.

The fact that there is no difference in long-term results between patients with long or short histories of dyspepsia does not, of course, mean that the criteria for operation should be relaxed, as this 'short-history' group is in any case only operated on for severity of bleeding and age. Rather, it means that if one is forced to operate on a patient without a significant history, according to the criteria mentioned, as good a long-term result can be expected as if there had been a long history of dyspepsia. There does, however, appear to be a significantly higher actual operative mortality rate if there is only a short history of dyspepsia.

With vagotomy and underrunning procedures, many reports suggest that the recurrent bleeding rates may be as high as $36 \%$ (Kelley et al, 1963; Hamilton, Harbrecht, Robbins, and Noland, 1965) although Foster, Hickock, and Dunphy (1965) report a rate of only $7 \%$. Recurrent bleeding rates after partial gastrectomy are usually quoted as around 5 to $8 \%$ (Foster et al, 1965), although Serebro and Mendeloff (1966) quote a long-term follow-up recurrent bleeding rate of $31 \%$.

The long-term recurrent bleeding rate in this series of $5 \%$ compares with $10 \%$ reported by Tanner (1964) for pyloroplasty and underrunning procedures which he did before the introduction of adjunctive vagotomy.

There have been relatively few long-term followup studies following surgery for ulcerative haemorrhage (Leape and Welch, 1964; Farris and Smith, 1967), but the recurrent ulcer rates appear to be significantly higher after operation for bleeding than when surgery is performed electively. Whereas in this series the recurrent ulcer rates are 3.6 and $7.3 \%$ for gastric ulcer and duodenal ulcer respectively, in the same hospital the elective recurrent ulcer rates are about $2 \%$ for both types of ulceration. Leape and Welch (1964) also found that their recurrent ulcer rates following gastrectomy for haemorrhage were double that following elective gastrectomy, and they considered that the ulcerative diathesis was probably more severe in those patients who present with bleeding than in those who presented for elective surgery. Farris and Smith (1967) had a re-operation rate of $5 \%$ over five to ten years after emergency surgery for bleeding duodenal ulcer, which is twice that for similar cases in this series.

The long-term clinical and biochemical results after partial gastrectomy in this series compare favourably with those after elective gastric resection in the same hospital (Tanner, 1959).

Which operation should be performed for bleeding gastroduodenal ulceration ? Goligher (1970), reporting on his controlled studies in Leeds, suggested that for elective operations there is little to choose between the overall results of gastric resection and vagotomy procedures, and our results would suggest that equally is this likely to apply for patients who present with bleeding. The benefits of better results will almost certainly come from better resuscitation techniques, both pre- and postoperatively, and earlier operation, particularly in the elderly age groups, rather than from which type of operation is chosen by any particular gastric surgeon.

Our sincere thanks are due to Mrs D. Cross for her secretarial work, and to the South West Metropolitan Regional Hospital Board and Research Committee without whose cooperation this work could not have been possible.

\section{Refcrences}

Desmond, A. M. (1962). Gastroduodenal haemorrhage: surgical management. Calif. Med., 96, 245-250.

Farris, J. M., and Smith, G. K. (1967). Appraisal of the long-term results of vagotomy and pyloroplasty in 100 patients with bleeding duodenal ulcers. Ann. Surg., 166, 630-639.

Foster, J. H., Hickok, D. F., and Dunphy, J. E. (1965). Changing concepts in the surgical treatment of massive gastroduodenal hemorrhage. Ann. Surg., 161, 968-976.

Foster, J. H., Hunt, T. K., and Dunphy, J. E. (1964). Emergency operation for massive upper gastrointestinal haemorrhage. Brit. J. Surg., 51, 757-758.

Goligher, J. C. (1970). The comparative results of different operations in the elective treatment of duodenal ulcer. Brit. J. Surg., 47, 780-783.

Hamilton, J. E., Harbrecht, P. J., Robbins, R. E., and Noland, J. L. (1965). The behaviour and management of major acute bleeding from peptic ulcers. Surg. Gynec. Obstet., 121, 545-550.

Kelley, H. G., Grant, G. N., and Elliott, D. W. (1963). Massive gastrointestinal haemorrhage. Arch. Surg., 87, 6-12.

Large, J. M. (1960). Gastroduodenal haemorrhage as a surgical emergency. Brit. med. J., 1, 932-935.

Leape, L. L., and Welch, C. E. (1964). Late prognosis of patients with upper gastrointestinal hemorrhage. Amer. J. Surg., 107, 297-305. 
MacCaig, J. N., Strange, S. L., and Norris, T. St. M. (1964). Haemorrhage from the upper alimentary tract. Gut, 5, 136-141.

Nielsen, S. P., and Amdrup, E. (1968). Mortality following surgical treatment for massive gastroduodenal hemorrhage. Acta chir. scand., Suppl., 396, pp. 29-35.

Schiller, K. F., Truelove, S. C., and Williams, D. G. (1970). Haematemesis and melaena, with special reference to factors influencing the outcome. Brit. med. J., 2, 7-14.
Serebro, H. A., and Mendeloff, A. I. (1966). Late results of medical and surgical treatment of bleeding peptic ulcer. Lancet, 2, 505-508.

Tanner, N. C. (1959). Discussion on the surgical management of chronic duodenal ulcer. Proc. roy. Soc. Med., 52, 840.

Tanner, N. C. (1964). The diagnosis and management of massive haematemesis. Brit. J. Surg., 51, 754-756.

Visick, A. H. (1948). A study of the failures after gastrectomy. Ann. Roy. Coll. Surg., 3, 266-284. 